\title{
PENGARUH KOMPOSIT SBR DAN KARET ALAM DENGAN PENGISI KARBON HITAM TERHADAP SIFAT FISIK DAN KETAHANAN USANG VULKANISAT
}

\section{THE EFFECT OF SBR AND NATURAL RUBBER COMPOSITES CARBON BLACK FILLED TOWARDS PHYSICAL CHARACTERISTICS AND AGEING RESISTANCE}

\author{
Nesi Susilawati*, Frima Roza1 ${ }^{1}$, Rifki ${ }^{1}$, Tri Susanto ${ }^{1}$ \\ ${ }^{1}$ Balai Riset dan Standardisasi Industri Palembang \\ 1 Jalan Perindustrian II No. 12 Sukarami KM. 09 Palembang 30152 \\ * main contributor and coresponding author \\ ${ }^{1}$ e-mail : nesisusilawati@kemenperin.go.id
}

Diterima: 26 Juni 2019 ; Direvisi: 26 Juni -25 November 2019 ; Disetujui: 16 Desember 2019

\begin{abstract}
Abstrak
Peningkatan kualitas tahan panas produk karet berbasis karet alam perlu ditingkatkan melalui pencampuran dengan karet sintetis seperti stirene butadiene rubber (SBR). Karet alam tidak tahan terhadap ozon dan panas, tetapi memiliki ketahanan kikis yang tinggi. Sedangkan karet sintetis tahan terhadap ozon, panas dan ketahanan retak. Penelitian ini bertujuan untuk mempelajari efek penambahan SBR terhadap meningkatnya sifat mekanik fisik. Proses pembuatan vulkanisat dilakukan sesuai dengan ASTM D-3182 dengan variasi perlakuan NR/SBR yaitu 100/0, 70/30, 60/40, 50/50, 40/60 dan 0/100 phr. Hasil penelitian menunjukkan bahwa tegangan putus vulkanisat naik signifikan karena penambahan SBR, walaupun akan berdampak negatif terhadap perpanjangan putus, modulus dan tear strength, namun efek penambahan SBR tidak signifikan untuk parameter kekerasan. Hasil uji pengusangan pada suhu $70^{\circ} \mathrm{C}$ selama 72 jam menunjukkan bahwa semakin banyak SBR, sifat ketahanan komposit SBR/NR semakin tinggi. Hal ini diperkuat dengan semakin kecilnya perubahan nilai kekerasan dan perpanjangan putus sebelum dan sesudah pengusangan.
\end{abstract}

Kata kunci : NR/SBR, Carbon Black, ASTM, Perpanjangan Putus, Ketahanan sobek

\begin{abstract}
The quality of heat-resistant rubber products based on natural rubber needs to be improved through mixing the products with synthetic rubber such as Styrene butadiene Rubber (SBR). Natural rubber is not resistant to ozone and heat, but it has high abrasion resistance. Meanwhile synthetic rubber is resistant to ozone, heat and cracks. This research aims to study the effect of adding SBR to the increasing physical mechanical properties of rubber compounds. The process of making vulcanizate was done in accordance with ASTM D3182 with variations in NR/SBR treatment of 100/0, 70/30, 60/40,50/50, 40/60 and 0/100 phr. The results show that tensile strength increased significantly due to the addition of $S B R$, although it has negative effect to the elongation of breaking, modulus and tear strength, but the effect of adding SBR was not significant for hardness parameters. It is concluded that the SBR loading may improve the heat resistance of the SBR-NR composites filled Carbon Black.
\end{abstract}

Keywords : NR/SBR, carbon black, ASTM, elongation of break, tear strength 


\section{PENDAHULUAN}

Kualitas barang jadi karet sangat ditentukan oleh bahan baku dan bahan tambahan yang digunakan serta teknologi cara pembuatannya. Karet dalam keadaan mentah tidak dapat dibentuk menjadi barang jadi karet yang layak digunakan karena tidak elastis dan mempunyai banyak kelemahan. Agar dihasilkan barang jadi karet yang layak digunakan, terlebih dahulu dibuat kompon karet dengan cara mencampurkan karet dengan bahan kimia lain lalu di vulkanisasi (Wahyudi, 2005).

Karet alam (KA) merupakan polimer biosintesis alami yang mempunyai sifat mekanis dan dinamis yang baik serta mempunyai karakteristik proses yang baik (Ismail et al., 2001; Sahakaro et al., 2009; Kinasih et al, 2016). Karet alam umumnya mempunyai sifatsifat mekanik yang lebih baik dibandingkan dengan karet sintetis, sedangkan karet sintetis mempunyai sifat-sifat yang baik terhadap kondisi lingkungan seperti panas, cuaca, minyak (Rahman, 2005; Nuyah 2012). Karet alam mempunyai kelemahan yaitu kurang tahan terhadap panas dan minyak, karet alam memiliki ketahanan kimia yang rendah (Yahya et al., 2011; Kinasih et al 2016). Sifat-sifat fisika yang baik dari karet alam dapat dipergunakan untuk berbagai keperluan rumah tangga, kendaraan bermotor sampai ke tingkat industri besar. Kadar ikatan tidak jenuh menyebabkan karet alam tidak tahan terhadap oksidasi dan ozon, untuk mengurangi kelemahan tersebut dilakukan modifikasi struktur molekul karet alam secara kimia ataupun fisika. (Nuyah, 2012).

Karet alam tidak tahan terhadap ozon dan panas, tetapi memiliki ketahanan kikis yang tinggi. Sedangkan karet sintetis tahan terhadap ozon, panas dan ketahanan retak. Material elastomer berbasis SBR memiliki ketahanan retak yang cukup baik, tahan air dan tahan terhadap cuaca (Hassan et al., 2012; Bahri dan Tornades, 2018).

SBR (Styrene Butadiene Rubber) adalah pengganti Karet Alam (NR), mempunyai karakteristik yang mirip dengan Natural Rubber yaitu kenyal, tidak mudah sobek, tahan gesek. Kelemahan dari SBR adalah tidak mempunyai kualitas self reinforcing yang sebagus NR, vulkanisat stirene butadiene mempunyai sifat daya regang rendah dan sifat kuat tariknya bergantung pada jumlah filler pada saat compounding. (Susanto,2016).

SBR atau Styrene Butadiene Rubber adalah karet sintetis yang tersusun atas monomer stirena dan butadiena. SBR banyak digunakan dalam pembuatan ban kendaraan bermotor. SBR mempunyai ketahanan kikis yang baik dan juga panas atau kalor yang ditimbulkan olehnya tergolong rendah. Tetapi styrene butadiene rubber yang tidak diberikan tambahan bahan penguat mempunyai kekuatan yang lebih rendah jika dibandingkan dengan vulkanisir karet alam.

Karakteristik vulkanisat SBR sangat bergantung pada jumlah dan jenis bahan pengisi yang ditambahkan pada saat proses komponding. Sebagian besar barang karet menggunakan bahan pengisi seperti berbagai jenis karbon hitam dengan jumlah sekitar 20$30 \%$ sebagai bahan pengisi penguat untuk meningkatkan sifat fisik dan mekaniknya. Karbon hitam memiliki keunggulan yaitu ukurannya yang halus mempermudah dispersi partikel kedalam matriks polimer, selain itu ikatan vander wals antara karbon hitam dengan matriks polimer akan menguatkan fraksi pengisi ke pengisi, dan akan meningkatkan nilai kekerasannya. (Susanto, 2016).

Pencampuran antara karet alam dan SBR diharapkan dapat menggabungkan dua sifat dasar karet sehingga dapat saling melengkapi. Beberapa penelitian tentang penggunaan SBR pernah dilakukan sebelumnya. Nuyah Tahun 2011 melaporkan tentang pengaruh penggunaan SBR dan NR terhadap sifat fisik kompon karet packing cap radiator dengan formula campuran styrene butadiene rubber (SBR) dan karet alam (NR) dengan variasi perbandingan SBR : NR adalah $90: 10,80: 20,70: 30,60: 40$ dan 50 : $50 \mathrm{phr}$ dengan menguji parameter kekerasan, tegangan putus, dan perpanjangan putus. Penelitian Arum Yuniari et al tahun 2013, dengan variasi pale crepe dan SBR : 80/20; 70/30; 60/40; 50/50 phr dan variasi 
sulfur 1 dan 1,5. Selanjutnya penggunaan SBR oleh Nasruddin tahun 2017, dengan memvariasikan silica, fly ash dan minyak sawit untuk produk peredam benturan paving block aspal karet. Penelitian Syamsul Bahri dan Aprillena tahun 2018, kombinasi RSS dan SBR untuk produk bantalan kaki untuk mebel dengan formula RSS/SBR sebanyak 100/0, 70/30, 50/50 dan 30/70 phr dengan menguji parameter kekerasan/hardness, tegangan putus/tensile strength, perpanjangan putus/elongation at break, tegangan tarik/modulus $100 \%$, ketahanan sobek/tear resistance, ketahanan kikis/abrassion dan pampatan tetap/compression set $25 \%$.

Penelitian ini bertujuan untuk mempelajari pengaruh penambahan SBR dalam NR dengan bahan pengisi karbon hitam terhadap sifat fisik mekanik dan ketahanan usang pada suhu $70{ }^{\circ} \mathrm{C}, 72$ jam, diamati melalui perubahan nilai kekerasan, tegangan putus, perpanjangan putus, modulus $300 \%$, ketahanan sobek. Hasil penelitian berupa formulasi vulkanisat diharapkan dapat berkontribusi dalam pengembangan teknologi material biokomposit untuk pembuatan produk barang karet

\section{Bahan}

\section{BAHAN DAN METODE}

Styrene Butadiene Rubber (SBR), Natural Rubber/ NR (Standard Indonesian Rubber/ SIR 20). Bahan kimia untuk bahan pencampur pembuatan kompon seperti $\mathrm{ZnO}$, Stearic Acid, Karbon hitam N330, MBTS, Sulphur, TMQ, p-phenylenediamine (6-PPD), parafin wax, DOP/Minarex oil, TMTD dan sulfur. Bahan pendukung, silicon emulsi.

\section{Peralatan}

Alat yang digunakan meliputi Mesin giling dua roll (Open mill), press hidrolik, , gunting, neraca analitik, sarung tangan, palu termometer infrared, Cetakan (moulding), Alat press dan peralatan uji.

\section{Metode Penelitian}

Dalam Penelitian ini dilakukan percobaan pembuatan beberapa kompon karet dengan memvariasikan karet alam (NR/SIR 20), karet sintetis (SBR) yaitu formula
1 (karet alam 100 phr, tidak menggunakan karet sintetis), formula 2 (karet alam $70 \mathrm{phr}$ dan karet sintetis $30 \mathrm{phr}$ ), formula 3 (karet alam $60 \mathrm{phr}$ dan karet sintetis $40 \mathrm{phr}$ ), formula 4 (karet alam 50 phr dan karet sintetis 50 phr), formula 5 (karet alam 40 phr dan karet sintetis 60 phr) dan formula 6 (tidak menggunakan karet alam, karet sintetis 100 phr).

\section{Prosedur Pembuatan Kompon karet}

\section{Penimbangan}

Bahan yang diperlukan untuk masing-masing formula kompon ditimbang sesuai perlakuan pada tabel 1 . Jumlah dari setiap bahan didalam formula kompon dinyatakan dalam phr (part hundred rubber).

\section{Mixing (pencampuran)}

Proses pencampuran dilakukan dalam gilingan terbuka (open mill) yang telah dibersihkan selanjutnya dilakukan proses :

1. Mastikasi karet alam selama 2-3 menit dengan temperatur $40-70^{\circ} \mathrm{C}$, dengan indikasi tidak ada bolongan lagi yang terdapat pada karet yang sedang dimastikasi.

2. Kemudian ditambahkan $\mathrm{ZnO}$, Stearic Acid, Karbon hitam N330, MBTS, Sulphur, TMQ, p-phenylenediamine (6-PPD), parafin wax, DOP/Minarex oil, TMTD. sulfur dan giling bersama karet alam.

3. Setelah campuran sudah dianggap homogen, kemudian giling lembaran kompon sebanyak 6 kali sampai mencapai kematangan yang diinginkan.

4. Lembaran kompon dikeluarkan dari open mill dan tentukan ukuran ketebalan lembaran kompon, kemudian letakkan di atas plastik transparan lalu diamkan selama 24 jam.

\section{Vulkanisasi dan Pencetakan Kompon Karet Cetak}

1. Lembaran kompon karet disiapkan dengan tebal $5 \mathrm{~mm}$, panjang $12 \mathrm{~cm}$, lebar $10 \mathrm{~cm}$ atau disesuaikan dengan permukaan cetakan yang akan dilapisi karet.

2. Siapkan cetakan, bersihkan, kemudian cetakan diolesi dengan silicon emulsi agar 
Nesi Susilawati, Frima Roza, Rifki dan Tri Susanto
Pengaruh Komposit SBR dan Karet Alam dengan Pengisi Karbon Hitam Terhadap Sifat Fisik dan Ketahanan Usang Vulkanisat karet tidak lengket pada cetakan dan masukkan kompon karet ke dalam cetakan.

3. Permukaan cetakan dilapisi lembaran kompon karet yang telah dipersiapkan dan jangan ada udara yang terjebak pada lapisan karet.

4. Setelah kompon matang, dinginkan dan buka cetakan sesuai produk yang akan dibuat.

Tabel 1. Formulasi kompon Campuran NR dan SBR.

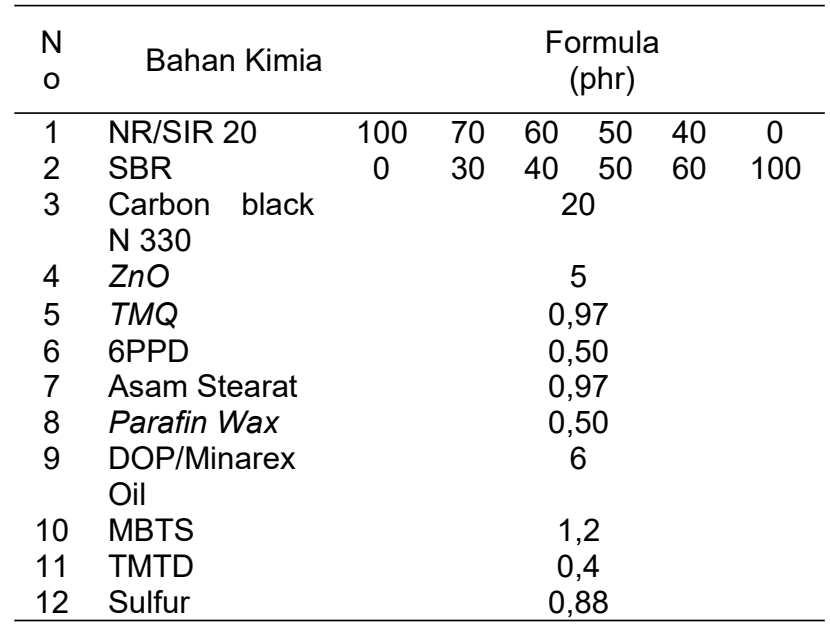

HASIL DAN PEMBAHASAN

\section{Kekerasan (Hardness)}

Uji kekerasan dilakukan untuk mengetahui besarnya kekerasan vulkanisat karet dengan kekuatan penekanan tertentu (Wahyudi, 2005; Nuyah,2012).

Hasil pengujian kekerasan kompon karet berkisar antara 70 hinggá 72 shore $A$, Hasil pengujian perubahan kekerasan pada beberapa formula kompon karet dapat dilihat pada Gambar 1.

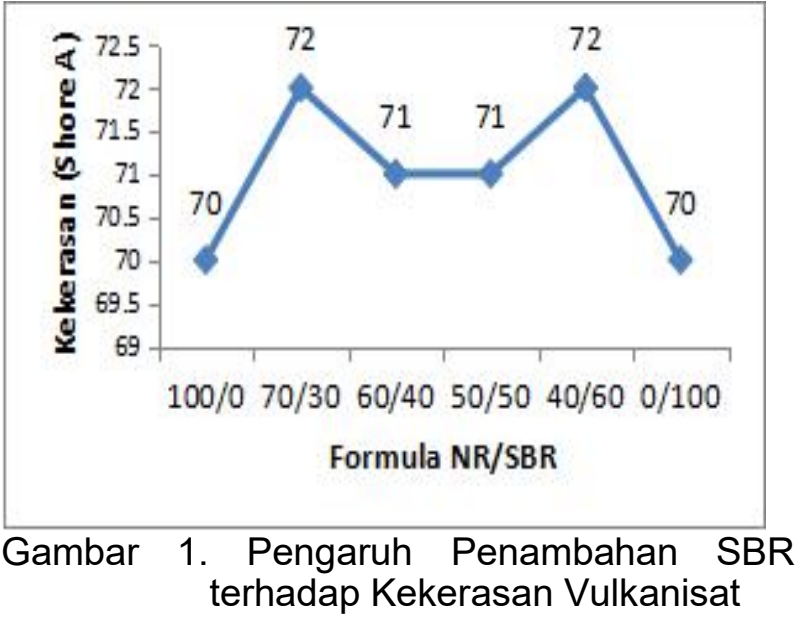

Dari gambar 1 terlihat bahwa variasi formula NR dan SBR tidak memberikan pengaruh yang signifikan terhadap parameter kekerasan. Penambahan karet alam (NR) cenderung menurunkan nilai kekerasan kompon karet. Hal ini disebabkan karet alam bersifat lentur dan mempunyai friksi yang baik pada suhu normal, sehingga pemakaian karet alam yang banyak akan membuat kompon karet menjadi lunak (Nuyah, 2011). Namun dari gambar 1 terlihat bahwa penggunaan karet sintetis juga dapat menurunkan kekerasan. Hal ini dapat disebabkan karena tambahan bahan pelunak minarex oil pada formula, seperti yang dilaporkan Nuyah dan Rahmaniar (2016) bahwa bahan pelunak dapat menurunkan sifat kekerasan karena bahan pelunak menurunkan jumlah ikatan silang yang terbentuk, sedangkan untuk mempertahankan jumlah ikatan silang tersebut, perlu ditambahkan bahan pemvulkanisasi. Vulkanisasi merupakan faktor yang sangat penting dalam teknologi barang jadi karet dan reaksi sambung silang (crosslinking) molekul-molekul karet oleh sulfur sehingga dihasilkan suatu vulkanisat karet yang elastic dan kuat (Sitorus, 2013; Suparto dan Santoso, 2003; Nuyah dan Rahmaniar, 2013). Penggunaan karet sintetis yang diberi tambahan bahan penguat akan memiliki kekerasan yang tinggi (Supratiningsih,2015; Nuyah,2011). 


\section{Tegangan Putus (Tensile strength)}

Tegangan putus merupakan besarnya beban yang diperlukan untuk meregangkan potongan uji sampai putus, dinyatakan dengan $\mathrm{kg}$ tiap $\mathrm{cm}^{2}$ luas penampang potongan uji sebelum diregangkan. Jika nilai tegangan putus semakin besar, menunjukkan bahwa kompon karet semakin elastis (Basseri, 2005; Nuyah, 2011). Pengujian tegangan putus juga menggambarkan tentang kekuatan dan kekenyalan karet (Marlina, P et al, 2014).

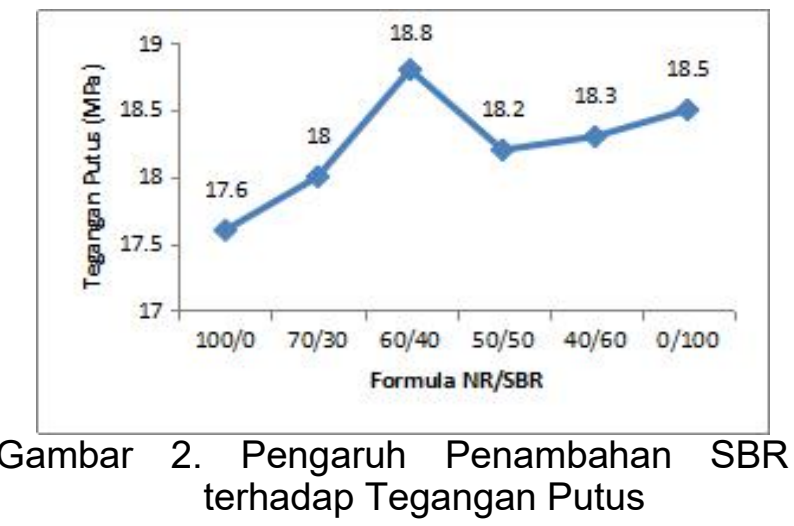

Dari gambar 2 terlihat bahwa nilai tegangan putus cenderung naik dengan penambahan SBR semakin banyak, hal ini karena karet sintetis SBR mengandung acrylonitrile yang berfungsi mempertahankan molekul karet tidak terputus selama proses mastikasi, sehingga daya elastisitasnya tinggi.(Rahman 2005; Nuyah, 2011).

Karet alam memiliki daya elastis atau daya lenting yang baik dan plastisitas tinggi, sehingga pada penambahan karet alam (NR) terjadi penurunan nilai tegangan putus kompon karet. (Nuyah, 2011). Tegangan putus vulkanisat sangat dipengaruhi oleh terbentuknya ikatan poly dan monosulphidic dan kerapatan ikatan silang. Semakin besar persentase terbentuknya crosslink polysulphidic, semakin tinggi nilai tegangan putus dan elastisitasnya (Yuniarti.A et al, 2013).

\section{Perpanjangan Putus}

Perpanjangan putus adalah pertambahan panjang suatu potongan uji bila diregangkan sampai putus, dinyatakan dengan persentase dari panjang potongan uji sebelum diregangkan (Marlina, $P$ et al, 2014). Pengujian perpanjangan putus bertujuan untuk mengetahui sifat-sifat tegangan dan regangan dari karet vulkanisat dan thermoplastik dan termasuk penentuan yield point melalui kekuatan dan pertambahan panjang vulkanisat karet ketika mengalami penarikan sampai perpanjangan tertentu dan sampai putus (Nuyah, 2011).

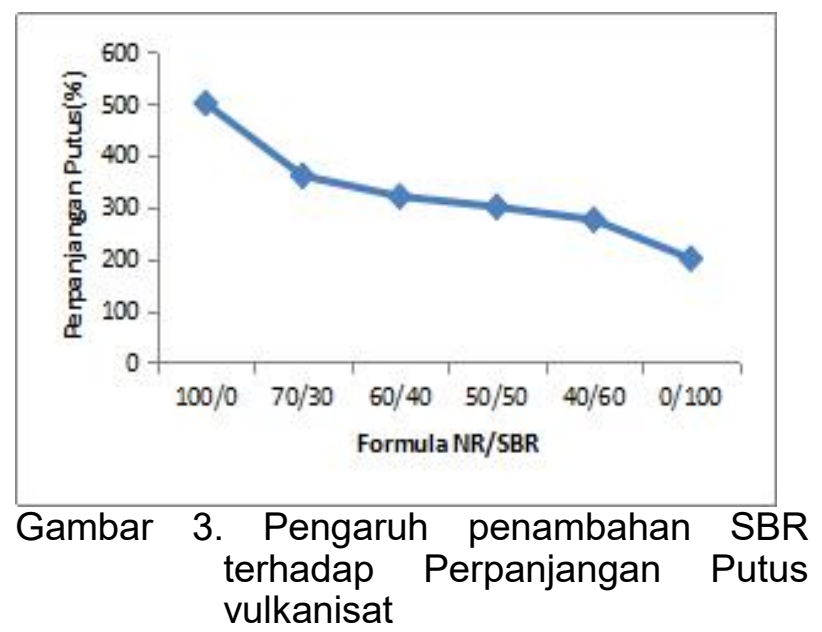

Dari Gambar 3 .terlihat bahwa dengan semakin banyak penambahan SBR, nilai perpanjangan putus cenderung semakin kecil. Hal ini selaras dengan sifat SBR yang mempunyai sifat elastis dan kelenturan yang kecil. Nilai perpanjangan putus yang cenderung kecil menunjukkan bahwa kompon tersebut cenderung tidak elastis. Semakin besar penambahan SBR, maka akan menurunkan sifat perpanjangan putus kompon karet maupun produk karet sehingga semakin tidak elastis. Karet alam (cis 1,4 poliisoprene) mempunyai keunggulan pada sifat perpanjangan putus maupun ketahanan sobek. (Nor \& Othman, 2016).

\section{Modulus $300 \%$}

Modulus merupakan bagian dari sifat mekanik yang berhubungan langsung dengan tenaga yang dibutuhkan usaha untuk meregangkan. Modulus dipengaruhi oleh mutu karet, rasio bahan pengisi, proses vulkanisasi, ikatan antar molekul pembentuknya, jenis bahan 
pelunak, dan sifat mekanik (Nasruddin,2017). Sulfur yang ditambahkan pada matriks polimer komposit, pada saat yang bersamaam terjadi pembentukan ikatan silang antar molekul yang menyebabkan peningkatan kekuatan tarik dan modulus (Al-Maamori dan Hamza, 2018 ; Nasruddin,2018).

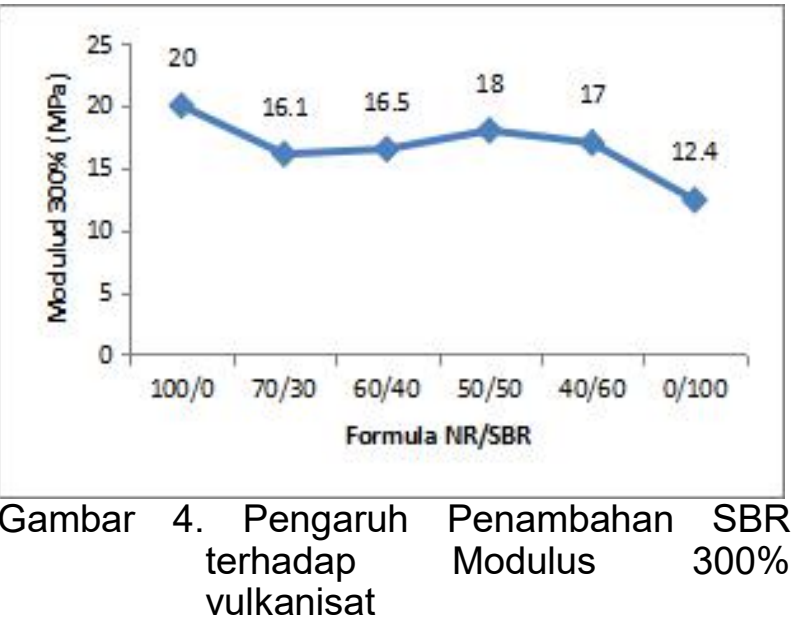

Data hasil pengujian untuk formula NR/SBR $=100 / 0$, nilai modulusnya tertinggi $(20 \mathrm{Mpa})$, Hal ini menunjukkan bahwa ikatan antar molekul, tingkat kerapatan, dan kekerasan untuk formula tersebut lebih baik. (Nasruddin, 2017).

Pengaruh penambahan karet sintetis (SBR) dalam karet alam terhadap modulus 300\% terlihat, dengan penurunan jumlah formula karet alam berpengaruh terhadap penurunan modulus dan sifat mekanik vulkanisat. Selain itu peningkatan jumlah karet sintetis berpengaruh terhadap penurunan elastisitas yang berdampak pada penurunan modulus. Fenomena penurunan modulus akibat berkurangnya karet alam ditemukan juga pada penelitian (Nasruddin, 2018).

\section{Ketahanan Sobek (Tear Strength)}

Ketahanan sobek merupakan besarnya gaya atau tenaga yang dibutuhkan untuk menyobek potongan uji sampai putus (Nuyah et al, 2012; Daud.D, 2015). Kenaikan ketahanan sobek berbanding lurus dengan perpanjangan putus dan berbanding terbalik dengan tegangan putus.

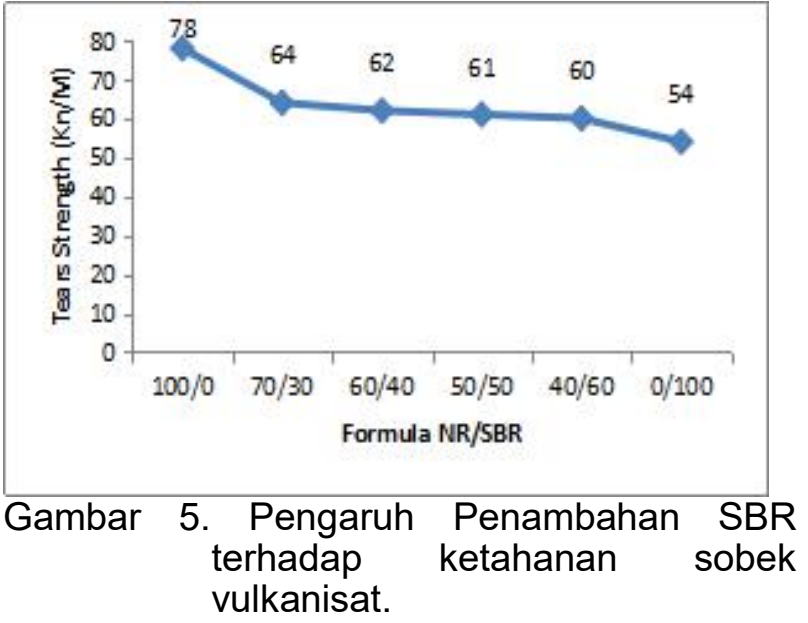

Dari gambar 5, dapat dilihat bahwa nilai ketahanan sobek (tear strength) cenderung turun seiring dengan penambahan SBR. Hal ini menunjukkan bahwa penambahan SBR menyebabkan rendahnya ketahanan sobek barang jadi karet akibat menurunnya daya elastisitasnya. Ketahanan sobek berkaitan dengan elastisitas, perpanjangan putus, dan kekerasan. Hal ini didukung oleh pernyataan Prasetya et al, 2013 dan Daud, 2015 yang melaporkan bahwa nilai ketahanan sobek kompon karet yang semakin besar, menunjukkan bahwa daya tahan terhadap sobekan karet semakin bagus. Ketahanan sobek berkaitan dengan energi pemutusan. Ketahanan sobek dipengaruhi oleh kesempurnaan terjadinya ikatan silang pada saat proses vulkanisasi karet dengan bahan yang membentuk vulkanisat. (Nasruddin, 2017).

\section{Karaketristik Pengusangan 72 jam suhu 70 ${ }^{0} \mathrm{C}$}

Pengusangan mengakibatkan turunnya sifat fisik barang karet seperti tegangan putus, perpanjangan putus dan kekerasan. Selama penyimpanan, karet akan menjadi keras, retak, lunak dan lengket. Penurunan sifat fisik tersebut akibat terjadinya degradasi karet karena oksidasi oleh oksigen dan ozon. Oksidasi dipercepat dengan adanya panas, sinar ultraviolet,dan logam logam yang mengkristalisasi oksidasi karet. Ketahanan 
usang kompon karet dinyatakan dengan kemunduran tegangan putus dan kekerasan.

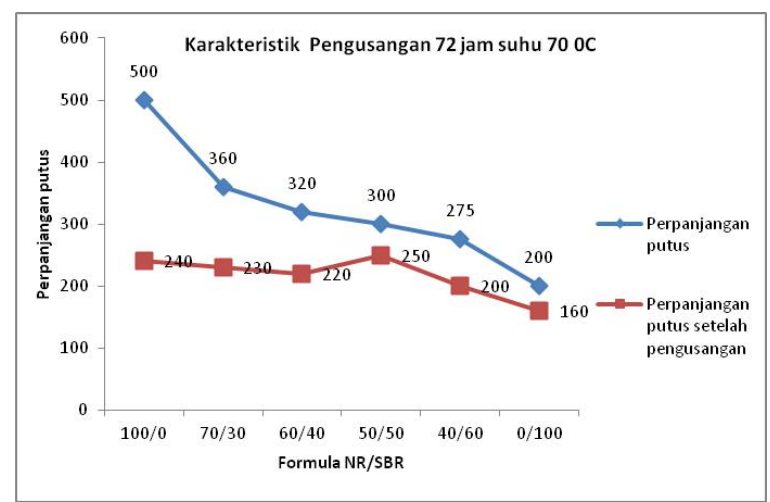

Gambar 6. Penurunan parameter perpanjangan putus setelah pengusangan 72 jam suhu $70{ }^{\circ} \mathrm{C}$

Hasil pengujian perpanjangan putus seperti pada gambar 6, sebelum pengusangan dan sesudah pengusangan tidak mengalami penurunan yang signifikan, hal ini menunjukkan bahwa kompon yang dihasilkan mempunyai karakteristik yang baik, tidak mengalami perubahan fisik akibat degradasi karena oksidasi oleh oksigen dan ozon yang dipercepat oleh adanya panas, sinat ultraviolet, dan logam. Hal ini berarti formula NR dan SBR mampu mempertahankan sifat elastis setelah pengusangan. Derajat keaktifan atau derajat penguatan ini berhubungan dengan besar partikel partikel bahan pengisi, makin kecil ukuran bahan pengisi makin besar keaktifannya (Marlina dan Rahmaniar, 2012).

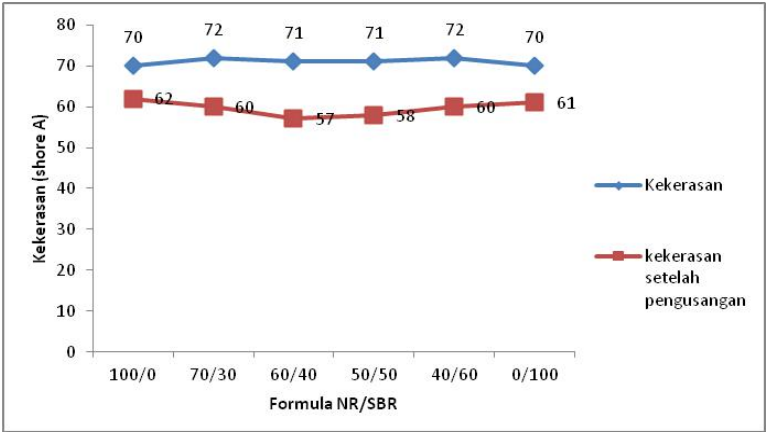

Gambar 7. Penurunan parameter kekerasan setelah pengusangan 72 jam suhu $70^{\circ} \mathrm{C}$
Dari Gambar 7 dapat dilihat bahwa hasil pengujian kekerasan setelah pengusangan pada $70{ }^{\circ} \mathrm{C}$ selama 72 jam menunjukkan nilai kekerasan tertinggi diperoleh pada formula NR/SBR $=100 / 0$ sebesar 62 Shore A. Bila dibandingkan dengan hasil uji kekerasan sebelum pengusangan nilai masing masing kompon sesudah pengusangan tidak jauh berbeda. Hal ini menunjukkan bahwa kompon yang dihasilkan mempunyai karakteristik yang baik, tidak mengalami perubahan fisik akibat degradasi karena oksidasi oleh oksigen dan ozon yang dipercepat oleh adanya panas, sinat ultraviolet, dan logam.

\section{KESIMPULAN}

Berdasarkan hasil penelitian, penambahan SBR pada Karet alam berdampak pada turunnya nilai perpanjangan putus, modulus $300 \%$ dan ketahanan sobek. $\mathrm{Di}$ sisi lain, penambahan SBR akan mengakibatkan peningkatan sifat tegangan putus, akan tetapi tidak berdampak signifikan terhadap kekerasan vulkanisat komposit tersebut. Hasil uji pengusangan pada suhu 70 ${ }^{\circ} \mathrm{C}$ selama 72 jam menunjukkan bahwa semakin banyak SBR, sifat ketahanan komposit SBR/NR semakin tinggi. Hal ini diperkuat dengan semakin kecilnya perubahan nilai kekerasan dan perpanjangan putus sebelum dan sesudah pengusangan.

\section{UCAPAN TERIMA KASIH}

Kontributor utama dalam karya tulis ilmiah ini menyampaikan terimakasih kepada Tri Susanto, S.Si, M.Si, M.AIE atas bimbingan, ide dan pemikiran untuk pelaksanaan penelitian dan masukannya sehingga karya tulis ilmiah ini dapat diterbitkan. Penulis juga berterimakasih kepada Wahyu Tri Saputra dan tim penelitian atas kerjasama dan dukungan dalam penelitian laboratorium maupun pengujian produk karet.

\section{DAFTAR PUSTAKA}

Al-Maamori, M.H., and Hamza, A.F. (2018). Effect of Sulfur and Nano-Carbon Black on the Mechanical Properties of Hard Rubber. Journal of University of Babylon. Engineering Sciences. 26(2): 127-134 
Basseri, A. (2005). Teori Praktek Barang Jadi Karet. Bogor: Balai Penelitian dan Teknologi Karet.

Bahri, S dan Tornades,A.B (2018). Kombinasi RSS dan SBR dalam Teknologi Pembuatan Karet Bantalan Kaki untuk Mebel. Jurnal Dinamika Penelitian Industri Vol. 29 Nomor 1 Tahun 2018. Hal. 12-18.

Daud,D (2015). Kaolin sebagai Bahan Pengisi pada Pembuatan Kompon Karet:Pengaruh Ukuran dan Jumlah terhadap Sifat Mekanik-Fisik. Jurnal Dinamika Penelitian Industri Vol.26 No.1 Tahun 2015, Hal. 4148.

Hassan, H. H., Ateia, E., Darwish, N. a., Halim, S. F., \& Abd El-Aziz, a. K. (2012). Effect of filler concentration on the physicomechanical properties of super abrasion furnace black and silica loaded styrene butadiene rubber. Materials and Design, 34, 533-540. http://doi.org/10.1016/j.matdes.2011.05.00 5

Ismail, H., Ahmad, Z., \& Mohd, I. Z. A. (2001). Com-parison of cetyltrimethyl ammonium maleate and sulphenamide as an accelerator in carbon black filled natural rubber compounds. Polymer Testing, 20, 607-614.

Kinasih,N.A \& Fathurrohman,N.I (2016), Ketahanan n-pentana dan sifat mekanis vulkanisat karet perapat dari campuran karet alam/akrilonitril-butadiena dengan kompatibiliser.Majalah Kulit, Karet, dan Plastik, 32(2), 99-110, 2016.

Marlina, P dan Rahmaniar (2012). Penggunaan Bahan pengisi nanokomposit silika karbida pada pembuatan kompon ban dalam kendaraan bermotor roda dua. Jurnal Dinamika Penelitian Industri Vo. 23 No. 2 (hal 91-98). Nasruddin (2017). Karakteristik Sifat Mekanik Solid Tyre Dengan Bahan Pengisi Dan Pelunak Berbasis Sumber Daya Alam Lokal. Jurnal Dinamika Penelitian Industri Vol. 28 Nomor 1 Tahun 2017, hal. 20-31

Nasruddin (2018). Sifat Mekanik Rubber Waves Dari Komposit Karet Alam Dan karet sintetis Menggunakan Multi Filler. Jurnal Dinamika Penelitian Industri Vol. 29 Nomor 1 Tahun 2018. Hal. 35 - 45

Nor, N. M., \& Othman, N. (2016). Effect of filler loading on curing characteristic and tensile properties of palygorskite natural rubber nanocomposites. Procedia Chemistry, 19, 351-358.

Nuyah (2011). Pengaruh Penggunaan SBR Dan NR Terhadap Sifat Fisika Kompon Karet Packing Cap Radiator Jurnal Dinamika Penelitian Industri Vol. 22 No. 1 Tahun 2011. Hal. 52-57

Nuyah (2012), Pengaruh Karet Alam Hidrogenasi terhadap Ketahanan Oksidasi dan Ozon Barang Jadi Karet.Jurnal Dinamika Penelitian Industri Vol. 23 No. 2 Tahun 2012 hal. Hal. 116-123

Nuyah dan Rahmaniar (2016). Pemanfaatan Pasir Kuarsa sebagai Bahan Pengisi dalam Pembuatan Karpet Karet. Jurnal Dinamika Penelitian Industri Vol. 27 No. 2 Tahun 2016. Hal 132-138.

Prasetya,H.,Marlina,P (2013). Sekam Padi sebagai Bahan Pengisi dan Anti Oksidan pada Pembuatan Kompon Karet. Jurnal Dinamika Penelitian Industri Vol. 24 No. 2 Tahun 2013. Hal. 66-73.

Prasetya, H dan Marlina P (2019). Pengaruh Bahan Pengisi Arang Tandan Kosong Kelapa Sawit terhadap swelling dan Ketahanan Usang Karet Kopling Kendaraan Motor Roda Dua. Jurnal Dinamika Penelitian Industri Vol. 30 Nomor 1 Tahun 2019 hal. 38-47

Rahman, N. (2005). Pengetahuan Dasar Elastomer. Kursus Teknologi Barang Jadi Karet Padat. Bogor: Balai Penelitian Teknologi Karet Bogor.

Sahakaro, K., Pongpaibon, C., \& Nakason, C. (2009). Improved mechanical properties of NR/EPDM blends by controlling the migration of curative and filler via reactive processing technique. Jour-nal of Applied PolymerScience, 111, 2035-2043, http://dx.doi.org/10.1002/app.29193.

Sitorus,I.M.S.,Widyanata, Y.,Surya,I. (2013). Pengaruh Penambahan Alkanolamida terhadap Karakteristik Pematangan dan Kekerasan Vulkanisat Karet Alam Berpengisi Kaolin. Jurnal Teknik Kimia USU. Vol. 2(\$) hal. 38-42.

Suparto,D dan Santoso,A.M (2003). Kimia dan Teknologi Barang Jadi Karet Padat. Balai Penelitian Teknologi Karet Bogor.

Supraptiningsih,A. (2005). Pengaruh RSS/SBR dan Filler $\mathrm{CaCO} 3$ terhadap Sifat Fisis Kompon Karpet Karet. Majalah Kulit, Karet dan Plastik 21(1);34-40. 
Susanto, T (2016),Perbandingan Sifat Mekanik Fisik Vulkanisat SBR dan SBR/NR Menggunakan Bahan Pengisi Pati Termodifikasi Resorcinol Formaldehyde. Jurnal Dinamika Penelitian Industri Vol. 27 No. 1 Tahun 2016. Hal. 09 - 18

Wahyudi, T. (2005). Teknologi Barang Jadi Karet. Bogor. Balai Penelitian Teknologi Karet Bogor.

Yahya, R. Y. S, Azura, A. R. \& Ahmad, Z. (2011). Effect of curing systems on thermal degradation behaviour of natural rubber (SMR CV 60). Journal of Physical Science, 22(2), 1-14...

Yuniarti, A, Sarengat,N, Lestari. S.B.P (2013). Pengaruh Sulfur terhadap sifat fisika campuran Pale crepe dan SBR untuk Karet Tahan Panas.Majalah Kulit, Karet dan Plastik Vol. 29 No.2 Desember Tahun 2013. Hal. 63-68. 